\title{
DIGLOSIA
}

Terakreditasi Sinta 3 | Volume 3 | Nomor 2 | Tahun 2020 | Halaman 189-196

P-ISSN 2615-725X | E-ISSN 2615-8655

http://diglosiaunmul.com/index.php/diglosia/article/view/32

\section{ANALISIS KESALAHAN BERBAHASA PENULISAN SURAT LAMARAN PEKERJAAN SISWA SMK AL-HUDA BUMIAYU}

\author{
An Error Analysis of Writing Application Letter by Students of Al-Huda Vocational School Bumiayu \\ Yeyen Yuniar ${ }^{1}$, Nur Azizah $^{2}$, Cintya Nurika Irma ${ }^{3, *}$ \\ ${ }^{1,2,3}$ Pendidikan Bahasa dan Sastra Indonesia, FKIP, Universitas Peradaban \\ ${ }^{1}$ Pos-el: eyenserang@gmail.com \\ ${ }^{2}$ Pos-el: nurazizahh896@gmail.com \\ 3,* Pos-el korespondensi: cintya_nurikairma@yahoo.co.id
}

\begin{abstract}
The purpose of this study is to analyze the language errors contained in the job application letter of SMK Al-Huda Bumiayu students. The method used in this research is descriptive method.This study uses data triangulation aimed to test the validity of the data. The analysis technique in this study uses three ways namely data reduction, data presentation, and drawing conclusions. Error writing job application letter written by Al-Huda Bumiayu Vocational School student Language errors found were (1) errors in writing prepositions, (2) errors in writing standard words, (3) errors in italics, and (4) mistakes in capital letters.
\end{abstract}

Keywords: language errors, applications letter, writing

Abstrak: Tujuan dari penelitian ini yaitu untuk menganalisis kesalahan berbahasa yang terdapat dalam surat lamaran pekerjaan siswa SMK Al-Huda Bumiayu. Metode yang digunakan dalam penelitian ini yakni metode deskriptif. Penelitian ini menggunakan triangulasi data bertujuan untuk menguji adanya keabsahan data. Teknik analisis dalam penelitian ini menggunakan tiga cara yaitu reduksi data, penyajian data, dan penarikan kesimpulan. Kesalahan penulisan surat lamaran pekerjaan yang ditulis siswa SMK Al-Huda Bumiayu Kesalahan berbahasa yang ditemukan yaitu (1) kesalahan penulisan kata depan, (2) kesalahan penulisan kata baku, (3) kesalahan penggunaan kata miring, dan (4) kesalahan penggunaan huruf kapital.

Kata kunci: kesalahan berbahasa, surat lamaran pekerjaan, menulis

\section{A. PENDAHULUAN}

Salah satu cara seseorang mengungkapkan pikiran atau perasaan terhadap orang lain atau lawan bicara dilakukan melalui komunikasi. Berkomunikasi menjadikan orang akan mendapatkan informasi. Pada dasarnya berkomunikasi suatu kegiatan yang sangat penting sekali, tanpa adanya komunikasi akan sangat sulit menerima informasi ataupun memberikan informasi. Berkomunikasi bisa dilakukan dengan dua cara yaitu secara lisan dan tulisan. Salah satu untuk berkomunikasi cara tulisan yaitu dengan menggunakan surat. Surat ditulis dengan bertujuan agar pembaca mengerti apa yang disampaikan oleh penulis. Surat ditujukan untuk menginformasikan atau memberitahukan maksud dari penulis dengan media tulisan.

Menulis merupakan kegiatan seseorang dalam menuangkan pikiran melalui tulisan-tulisan. Dengan menulis bisa menghasilkan berbagai tulisan yang 
menarik, apalagi hasilnya bisa mendapatkan suatu keuntungan. Kegiatan menulis bertujuan untuk menuangkan hasil gagasan atau pikiran maupun perasaan ke dalam bentuk tulisan yang dapat dipahami dan dimengerti oleh pembaca. dalam komunikasi tulis terdapat beberapa unsur yakni (1) penulis sebagai penyampai pesan, (2) isi tulisan atau pesan, (3) medianya berupa tulisan dan (4) pembaca sebagai penerima pesan (Lita, 2018, hal. 1). hal ini diperkuat oleh Yunus (2008, hal. 13) yang menyatakan bahwa menulis merupakan komunikasi dengan menggunakan bahasa tulis.

Standar kompetensi pembelajaran menulis adalah mampu mengungkapkan gagasan, pendapat dan perasaan (Depdiknas, 2005, hal. 33). Pembelajaran tentang menulis tentunya sangat penting untuk semua kalangan karena mengingat hal ini untuk ke depannya, yakni untuk membuat sebuah tulisan. Dengan pembelajaran menulis maka kita dapat menulis sebuah tulisan yang baik dan benar sesuai dengan Pedoman Umum Ejaan Bahasa Indonesia (PUEBI) walaupun masih saja terdapat kesalahan dalam penulisan dalam sebuah tulisan. Dapat diketahui bahwa salah satu contoh media tulis yaitu surat, ada surat pribadi dan surat resmi. Surat pribadi ialah surat yang ditulis seseorang berisi hubungan pribadi antara orang lain (yang dituju).

Surat pribadi yang sifatnya setengah resmi seringkali dibuat oleh seseorang yang ingin melamar pekerjaan. Contoh dari surat pribadi yang sifatnya setengah resmi yaitu surat lamaran pekerjaan. Surat lamaran pekerjaan adalah Surat lamaran pekerjaan tentunya dibuat oleh mereka yang akan melamar suatu pekerjaan ke suatu lembaga perusahaan. Surat lamaran pekerjaan biasanya dibuat atau ditulis oleh seseorang yang dikirimkan kepada instansi untuk melamar pekerjaan yang ada di instansi tersebut. Pendekatan yang tepat dalam kegiatan pembelajaran adalah pendekatan pembelajaran yang memberikan penekanan aspek keterampilan berbahasa dalam praktik komunikasi keseharian (Ely, 2017, hal. 1). Bahasa yang digunakan dalam surat lamaran pekerjaan harus baku, baik, dan sopan. Surat lamaran pekerjaan perlu memberikan gambaran terkait kualifikasi pelamar.

Penulisan dalam surat lamaran pekerjaan diperlukan mempunyai kemampuan dalam kebahasaan yang tinggi. Pada saat menulis surat lamaran pekerjaan tidak hanya penulisan yang rapi, namun unsur kebahasaan pun harus diperhatikan. Selain itu, harus memerhatikan bahasa yang digunakan yaitu menggunakan bahasa baku. Sapaan yang digunakan dalam surat lamaran pekerjaan menggunakan Ibu atau Bapak, tidak disarankan menggunakan kata Saudara atau Anda. Pelamar tidak boleh menggunakan kata kami, tetapi menggunakan kata saya (Maskurun et al., 2018, hal. 4).

Kemampuan menulis surat lamaran pekerjaan merupakan kemampuan yang penting dan harus dikuasai oleh semua siswa. Keterampilan menulis merupakan salah satu tujuan akan adanya pendidikan. Kenyataan yang terjadi di lapangan saat ini, masih banyak ditemukan kesalahan yang dilakukan oleh siswa dalam menulis surat lamaran pekerjaan. Kesalahan yang paling banyak dilakukan oleh siswa dalam pembelajaran menulis surat lamaran pekerjaan ialah kesalahan berbahasa. Kesalahan berbahasa merupakan penggunaan bahasa yang dilakukan dengan menyimpang dari kaidah kebahasaan yang berlaku dalam bahasa itu atau dalam ketentuan bahasa tersebut.

Markhamah \& Sabardila (2014) dalam kaitannya dengan kesalahan berbahasa membedakan antara istilah kesalahan berbahasa (error) dengan kekeliruan berbahasa (mistake). Menurut Ariningsih et al. (2012, hal. 42) kesalahan ialah penyimpangan yang bersifat sistematis, konsisten, dan menggambarkan 
kemampuan peserta didik pada tahap tertentu (yang biasanya belum sempurna). Sedangkan kekeliruan adalah bentuk penyimpangan yang tidak sistematis, yang berada pada wilayah performansi atau perilaku berbahasa. Kekeliruan berbahasa yang terjadi bukan karena siswa belum menguasai kaidah bahasa, namun dalam menggunakan bahasa terkadang mereka lupa atau keliru dalam menerapkan kaidah kebahasaan.

Penggunaan bahasa yang salah seringkali dilakukan oleh setiap siswa yang kurang memahami kaidah kebahasaan. Sesuai dengan pendapat Rofii (2014, hal. 2) menyatakan bahwa namun pada kenyataan yang terjadi saat ini, masih banyak ditemukan kesalahan yang dilakukan oleh siswa dalam menulis surat resmi. Kesalahan itu karena kurangnya pemahaman siswa terhadap aturan-aturan yang ada. Jadi, timbullah kesalahan berbahasa dalam surat lamaran pekerjaan. Selain itu, kesalahan berbahasa pun disebabkan oleh faktor pemahaman, kemampuan atau kompetensi siswa terhadap bahasa yang sedang dipelajari. Kurangnya perhatian siswa terhadap materi tentang kebahasaan.

Kesalahan penulisan surat lamaran pekerjaan yang ditulis siswa SMK Al-Huda Bumiayu contohnya kesalahan dalam bidang morfologi, bidang sintaksis, dari ejaannya, dan kurangnya pemahaman tentang PUEBI. Pembelajaran bahasa harusnya lebih menekankan fungsi bahasa sebagai alat komunikasi daripada pembelajaran tentang sistem bahasa (Depdiknas, 2003, hal. 2). Oleh karena itu, pembelajaran surat lamaran pekerjaan sangat diperlukan untuk semua siswa agar tahu bagaimana penyusunan surat lamaran pekerjaan yang sesuai aturan. Banyak sekali kesalahan yang ditemukan di dalam surat lamaran pekerjaan siswa SMK AlHuda Bumiayu, tidak hanya satu, dua, atau tiga siswa yang melakukan kesalahan penulisan tetapi rata-rata ada kesalahannya.
Penelitian ini akan mengkaji terkait kesalahan penulisan surat lamaran pekerjaan yang ditulis oleh siswa SMK AlHuda Bumiayu. Selain itu penelitian ini akan mendeskripsikan bentuk-bentuk dari kesalahan penulisan surat lamaran pekerjaan siswa SMK Al-Huda Bumiayu. Tujuan dari penelitian ini memaparkan jenis-jenis kesalahan berbahasa dalam surat lamaran pekerjaan pada siswa SMK Al-Huda Bumiayu. Dari penelitian inilah bisa diketahui macam-macam kesalahan yang ada dalam surat lamaran pekerjaan pada siswa SMK Al-Huda Bumiayu.

\section{B. METODE}

Penelitian ini dilaksanakan di SMK Al-Huda Bumiayu, Kecamatan Bumiayu, Kabupaten Brebes. Penelitian ini pun dilakukan pada bulan September 2019. Objek penelitian ini adalah hasil penulisan surat lamaran pekerjaan pada siswa kelas XII TKJ 4 SMK Al-Huda Bumiayu, Kecamatan Bumiayu, Kabupaten Brebes. Penelitian ini berupa penelitian deskriptif Metode dalam penelitian ini adalah metode baca dan catat. Data dalam penelitian ini surat lamaran pekerjaan pada siswa SMK Al-Huda Bumiayu kelas XII TKJ 4. Sumber data yang digunakan dalam penelitian ini adalah artikel yang relevan dan buku teori.

Teknik pengambilan sampel yang digunakan dalam penelitian ini adalah membaca dan mencatat bentuk-bentuk kesalahan berbahasa surat lamaran pekerjaan pada siswa SMK Al-Huda Bumiayu. Data dikumpulkan dengan cara mengelompokkan bentuk kesalahankesalahan berbahasa sesuai dengan jenisnya. Cara tersebut guna memperoleh informasi yang valid mengenai kesalahan berbahasa pada surat lamaran pekerjaan siswa SMK Al-Huda Bumiayu kelas XII TKJ 4. Penelitian ini menggunakan triangulasi data bertujuan untuk menguji adanya keabsahan data. Teknik analisis dalam penelitian ini menggunakan tiga 
cara yaitu reduksi data, penyajian data, dan penarikan kesimpulan.

\section{PEMBAHASAN}

Berikut bentuk kesalahan-kesalahan berbahasa yang terdapat di dalam surat lamaran pekerjaan pada siswa SMK AlHuda Bumiayu kelas XII TKJ 4. Bentuk kesalahannya dijelaskan sebagai berikut.

\section{Kesalahan Penulisan Kata Depan}

Kata depan di, ke, dan dari terpisah dari kata yang mengikutinya, kecuali jika beberapa gabungan kata yang sudah padu benar, seperti kepada dan daripada (Markhamah \& Saabardila, 2014, hal. 132). Jadi, kata depan ke, di, dan dari ditulis secara terpisah. Adapun kesalahan penulisan kata depan di dalam surat lamaran pekerjaan pada siswa SMK AlHuda Bumiayu dijelaskan di bawah ini.

\section{Data 1}

Saya sangat berharap di berikan ke sempatan untuk dapat mengikuti tes selanjutnya.

Kutipan di atas yaitu terdapat kesalahan penulisan kata depan di dan ke. Kata depan di dan ke seharusnya ditulis secara terpisah dengan kata yang mengikutinya.

Berikut ini bentuk pembenarannya:

Saya sangat berharap diberikan kesempatan untuk dapat mengikuti tes selanjutnya.

\section{Data 2}

Saya mengajukan surat lamaran kerja kepada Bapak/Ibu pimpinan agar sekiranya di terima sebagai karyawan perusahaan yang Bapak/Ibu pimpin.

Kutipan di atas terdapat kesalahan penulisan kata depan di. Kata depan di seharusnya dipisah dengan kata yang mengikutinya. Namun, dalam kutipan di atas tidak dipisah melainkan digabung.
Berikut ini bentuk pembenarannya:

Saya mengajukan surat lamaran kerja kepada Bapak/Ibu pimpinan agar sekiranya diterima sebagai karyawan perusahaan yang Bapak/Ibu pimpin.

\section{Data 3}

Fotokopi ijazah terakhir yang telah $\underline{\text { di }}$ sahkan.

Kutipan di atas terdapat kesalahan penulisan kata depan di. Kata depan di seharusnya ditulis serangkai dengan kata yang mengikutinya disebabkan bukan penunjukan tempat.

Berikut ini bentuk pembenarannya: Fotokopi ijazah terakhir yang telah disahkan.

\section{Kesalahan Penulisan Kata Baku}

Kesalahan penulisan dikarenakan tidak memerhatikan kaidah kebahasaan atau PUEBI. Penulisan harus sesuai dengan aturan-aturan yang ada di PUEBI. Dalam penulisan surat lamaran pekerjaan diperlukan ketelitian penulisan kata-kata baku. Surat lamaran yang ditulis oleh siswa SMK Al-Huda Bumiayu terdapat kesalahan penulisan tidak baku. Adapun kesalahannya dijelaskan sebagai berikut.

Data 1

Fotocopy ijazah

Bentuk kesalahan dari kutipan di atas yaitu penulisan kata fotocopy. Dalam Kamus Besar Bahasa Indonesia kata fotocopy seharusnya ditulis dengan fotokopi. Fotokopi bentuk penulisan baku dari kata fotocopy yang memiliki arti hasil reproduksi (penggandaan) fotografis terhadap barang cetakan (tulisan).

\section{Data 2}

Fotokopi transkrip nilai yg telah disahkan.

Bentuk kesalahan dari kutipan di atas yaitu penulisan yang. Kata konjungsi yang 
seharusnya ditulis secara lengkap, tidak boleh disingkat. Pada aturan dalam PUEBI singkatan hanya berlaku untuk (1) singkatan nama orang, gelar, jabatan atau pangkat, (2) singkatan terdiri dari huruf awal setiap kata nama lembaga pemerintah dan ketatanegaraan, lembaga pendidikan, badan atau organisasi serta nama dokumen resmi, (3) singkatan terdiri dari huruf awal setiap kata bukan nama diri, (4) singkatan terdiri dari tiga huruf, (5) singkatan terdiri dari dua huruf dan lazim digunakan dalam surat-menyurat, (6) lambang kimia, satuan ukuran, dan mata uang, (7) dan akronim.

\section{Data 3}

Sekian dan terimakasih

Kutipan di atas terdapat kesalahan penggunaan kata baku, yaitu kata terima kasih yang memiliki arti ungkapan rasa syukur. Kata terima kasih seharusnya ditulis secara terpisah.

\section{Kesalahan Penulisan Kata Miring}

Penggunaan kata miring dipergunakan untuk penulisan kata bahasa asing. Jadi, ketika penulisan menemukan bahasa asing, maka harus ditulis secara miring. Dalam penulisan surat lamaran pekerjaan siswa SMK Al-Huda Bumiayu terdapat kesalahan dalam menggunakan kata miring. Adapun kesalahannya dijelaskan berikut ini.

\section{Data 1}

Sehingga menjadikan saya untuk berminat part time di perusahaan yang Bapak/Ibu pimpin.

Kutipan di atas terdapat kesalahan mengenai penulisan kata miring. Bahasa asing atau bahasa selain bahasa Indonesia harus ditulis secara miring. Namun, pada kenyataannya dalam surat lamaran pekerjaan siswa SMK Al-Huda Bumiayu kata asing tidak ditulis secara miring. Kalimat di atas seharusnya ditulis:
Sehingga menjadikan saya untuk berminat part time di perusahaan yang Bapak/Ibu pimpin.

\section{Data 2}

Sesuai dengan iklan lowongan pekerjaan dari PT. Epson Indonesia, saya ingin bergabung ke dalam tim accounting di PT. Epson Indonesia.

Bentuk kesalahan yang ada dalam kutipan di atas yaitu kesalahan mengenai penulisan kata miring. Bahasa asing atau bahasa selain bahasa Indonesia harus ditulis secara miring. Namun, pada kenyataannya dalam surat lamaran pekerjaan siswa SMK Al-Huda Bumiayu kata asing tidak ditulis secara miring. Selanjutnya, penulisan PT. tidak ditulis dengan tanda baca titik. Kalimat di atas seharusnya ditulis:

Sesuai dengan iklan lowongan pekerjaan dari PT Epson Indonesia, saya ingin bergabung ke dalam tim accounting di PT Epson Indonesia.

\section{Data 3}

Saya juga menguasai berbagai aplikasi komputer seperti microsoft office dan yang lainnya.

Bentuk kesalahan yang terdapat dalam kutipan di atas yaitu kesalahan penulisan kata miring untuk bahasa asing. Dalam surat lamaran pekerjaan yang ditulis siswa SMK Al-Huda Bumiayu tidak menuliskan bahasa asing dengan ditulis miring. Kalimat di atas seharusnya ditulis:

Saya juga menguasai berbagai aplikasi komputer seperti microsoft office dan yang lainnya.

\section{Kesalahan Penulisan Huruf Kapital}

Penggunaan huruf kapital dalam penulisan kalimat harus diperhatikan dengan jelas, sebab jika tidak akan terdapat kesalahan-kesalahan yang terjadi jika tidak 
memperhatikannya. Maka dari itu kita perlu mengetahui terlebih dahulu penggunaan huruf-huruf kapital dalam suatu kata. Kesalahan-kesalahan seperti itu kerap kali terjadi dan ditemukan di surat undangan, surat kabar, surat lamaran pekerjaan dan masih banyak yang lainnya. Dalam hal ini ditemukan banyak sekali kesalahan penggunaan huruf kapital pada surat lamaran pekerjaan siswa SMK AlHuda Bumiayu.

\section{Data 1}

Bumiayu, 12 oktober 2019

Data di atas terdapat kesalahan penggunaan dalam penulisan huruf kapital pada penulisan kata yang menunjukkan bulan, yakni Oktober. Seharusnya di awal kata pada penulisan bulan ditulis dengan huruf kapital sehingga perbaikannya menjadi:

Bumiayu, 12 Oktober 2019

Data 2

Kepada $\underline{\text { YTH }}$

Kutipan di atas termasuk dalam kategori kesalahan penggunaan huruf kapital. Penulisan YTH adalah bentuk akronim dari yang terhormat, jadi seharusnya ditulis dengan huruf kapital di awal saja menjadi Yth. Selanjutnya, singkatan tersebut terdiri dari tiga huruf, sehingga diikuti dengan tanda titik di akhirnya.

\section{Data 3}

Perusahaan Yang Bapak/Ibu pimpin.

Terdapat kesalahan penggunaan huruf kapital, yakni kata yang. Kata yang tidak perlu ditulis dengan diawali huruf kapital karena bukan nama kota, nama orang, nama hari dan lain sebagainya. Jadi, penulisan yang tepat adalah: Perusahaan yang Bapak/Ibu pimpin.

\section{Data 4}

Daftar riwayat hidup Sebanyak Satu lembar

Penggunaan huruf kapital, yakni pada kata sebanyak dan satu. Kata tersebut seharusnya ditulis tanpa menggunakan huruf kapital. Jadi, penulisan kalimat yang benarnya adalah: Daftar riwayat hidup sebanyak satu lembar.

\section{Data 5}

PT. Pokphand indonesia

Kalimat di atas terdapat kesalahan penggunaan huruf kapital dalam kata Indonesia. seharusnya kata tersebut ditulis dengan diawali huruf pertama kapital dan tidak menggunakan tanda baca titik pada singkatan PT. Kalimat yang benar ditulis: PT Pokphand Indonesia.

\section{Data 6}

Adi tio Saputra

Data dari kutipan surat di atas termasuk dalam kategori kesalahan penggunaan huruf kapital. Nama orang seharusnya ditulis dengan huruf kapital pada huruf pertama setiap katanya. Penulisan nama yang benar dari di atas adalah Adi Tio Saputra.

Hasil penelitian dilakukan terkait kesalahan berbahasa pada surat lamaran pekerjaan yang ditulis siswa SMK Al-Huda Bumiayu kelas XII TKJ, terdapat empat kesalahan yang ditemukan, yaitu: (1) penulisan kata depan, (2) penulisan kata baku, (3) penulisan kata miring, dan (4) penulisan huruf kapital. Temuan kesalahan penulisan ini karena siswa belum mengetahui penulisan yang benar sesuai dengan KBBI dan PUEBI, meskipun sudah diperkenalkan dan diajarkan oleh guru. Oleh karena itu, pembiasaan dan koreksi perlu dilakukan secara berkelanjutan. Proses ini akan menjadikan siswa untuk mengulas kembali 
kemampuan berpikir kritis (HOTS) yang dimilikinya dalam tahap mengingat, menyatakan kembali atau merujuk sumber literatur. Seperti yang diungkap Brookhart (dalam Sutami, 2010, hal. 103) bigher order thinking conceived of as the top end of the Bloom's cognitive taxonomy. The teaching goal behind any of the cognitive taxonomies is equipping students to be able to do transfer. "Being able to think" means students can apply the knowledge and skills they developed during their learning to new contexts. "New" here means applications that the student has not thought of before, not necessarily something universally new. Higher order thinking is conceived as students being able to relate their learning to other elements beyond those they were taught to associate with it.

\section{PENUTUP}

Berdasarkan hasil penelitian terhadap kesalahan berbahasa dalam surat lamaran pekerjaan pada siswa SMK Al-Huda Bumiayu kelas X TKJ 4, yaitu menganalisis dua puluh surat lamaran pekerjaan yang dibuat oleh siswa. Dalam penelitian ini dapat disimpulkan bahwa kesalah penulisan paling banyak ditemukan pada kesalahan penulisan huruf kapital sebanyak enam data, dan kesalahan penulisan hampir sama ditemukan tiga data dilakukan pada penulisan kata depan, penulisan kata baku, dan penulisan kata miring.

\section{DAFTAR PUSTAKA}

Ariningsih, N. E., Sumarwati, \& Saddhono, K. (2012). Analisis Kesalahan Berbahasa Indonesia dalam Karangan Eksposisi Siswa Sekolah Menengah Atas. Basastra: Jurnal Penelitian Bahasa, Sastra Indonesia, dan Pengajarannya, 1(1), 4053.

Depdiknas. (2003). Pedoman Khusus Pengembangan Silabus dan Sistem Penilaian Mata Pelajaran Bahasa dan Sastra Indonesia. Jakarta.
Depdiknas. (2005). Kurikulum 2004 SMA Pedoman Khusus Pengembangan Silabus Berbasis Kompetensi Siswa Sekolah Mengengah Atas (SMA). Jakarta.

Putro, E. P. S. (2017). Peningkatan Kemampuan Menulis Surat Lamaran Pekerjaan Melalui Metode Team Game Tournament (TGT) pada Siswa Kelas XII IS 3 SMA Kristen 1 Surakarta. Kajian Linguistik dan Sastra, 19(2), 163-172.

Manalu, L. S., \& Arif, S. (2018). Peningkatan Kemampuan Menulis Surat Lamaran Pekerjaan Menggunakan Metode Pembelajaran STAD bagi Siswa Kelas XII IPA SMA Negeri 14 Medan Tahun Pembelajaran 20182019. Prosiding Seminar Nasional Pendidikan Bahasa dan Sastra Indonesia I Unimed-2018, 215-222.

Markhamah \& Sabardila, A. (2014). Analisis Kesalaban dan Karakteristik Bentuk Pasif. Surakarta: Muhammadiyah University Press.

Maskurun, et al. (2018). Bahasa Indonesia $S M A / M A / S M K$. Yogyakarta: LP2IP.

Rokhmansyah, A., Rijal, S., \& Purwanti. (2018). Bahasa Indonesia untuk Perguruan Tinggi. Semarang: Unnes Press.

Rofii, A. (2014). Analisis Kesalahan Berbahasa Indonesia dalam Surat Resmi pada Bidang Sintaksis Siswa Kelas VII MTs N Lubuk Buaya Kota Padang. Jurnal Imiah Dikdaya, 5(1), 1-14.

Sutami. (2020). Pengembangan Instrumen Asesmen Higher Order Thinking Skills (HOTS) pada Mata Pelajaran Bahasa Indonesia SMA dan SMK. Diglosia: Jurnal Kajian Bahasa, Sastra, dan Pengajarannya, 3(1), 102-113.

Yunus, M. (2006). Keterampilan Dasar Menulis. Jakarta: Universitas Terbuka.

Permatasari, N. E., Khasanah, I. M., \& Putri, N. A. M. (2019). Kesalahan 
Berbahasa dalam Majalah Pandawa IAIN Surakarta Edisi 2018 pada Tataran Ejaan dan Sintaksis. Diglosia: Jurnal Kajian Bahasa, Sastra, dan Pengajarannya, 2(2), 103-114.
Mulawarman, W. G., \& Noviyanti, N. (2020). Manajemen Bahasa Penulisan Proposal Mahasiswa Nonkebahasaan. Diglosia: Jurnal Kajian Bahasa, Sastra, dan Pengajarannya, 3(1), 53-64. 